\title{
Diverse Gram-positive bacteria identified from raw and pasteurized cow milk consumed at Gondar town and its environs, Ethiopia
}

\author{
Legesse Garedew ${ }^{1^{\star}}$, Desalegne Mengesha ${ }^{1}$, Ayalew Birhanu ${ }^{1}$, and Ali Mohammed ${ }^{1}$ \\ ${ }^{1}$ Faculty of Veterinary Medicine, University of Gondar, P. O. Box 196, Gondar, Ethiopia. \\ *Corresponding author: email: legesse_lg@yahoo.com
}

\begin{abstract}
Bacterial agents, especially gram-positive bacteria as they are widely distributed in the environment, may contaminate milk all the way from udder of the cow to finished products. This cross-sectional study was carried out from October 2010 to May 2011 on contamination of milk meant for human consumption in Gondar town, Ethiopia. Milk samples were collected from critical control points that were hypothesized to be sources of potential contamination including smallholder milk producers, dairy co-operatives, a milk processing plant, and supermarkets. The hygienic procedures applied during milking, milk collection, transportation, pasteurization, and post pasteurization storage conditions were evaluated. Standard bacteriological cultivation and biochemical assays were used to isolate and identify bacterial species. The results of the current study showed that conditions for contamination of raw milk at different critical points were due to less hygienic practices in udder preparation, sub-optimal hygiene of milk handlers, and poor sanitation practices associated with milking and storage equipment. This was evidenced by the dominant presence of Staphylococcus aureus and Bacillus cereus that can lead to public health hazard due to food poisoning related to enterotoxin production. Out of 140 gram-positive species identified, coagulase positive $(32.15 \%)$ and coagulase negative (15.71\%) Staphylococcus species, Rhodococcus equi (18.57\%), Bacillus cereus (12.86\%), Nocardia asteroids (5.71\%) and Micrococcus species (5\%) were the most commonly identified pathogens. Generally, $71.43 \%$ of the isolates were categorized under cocci while the remaining isolates were rods. In conclusion, this study showed the presence of diverse pathogenic gram-positive bacterial species in raw and pasteurized milk in Gondar town. These results highlighted the need to maintain appropriate sanitary and hygienic measures at each critical point in order to safeguard consumers from food borne pathogens.
\end{abstract}

Keywords: Bacteria, Critical control points, Hygiene, Milk. 


\section{Introduction}

Milk is a very nutritious food, which is rich in carbohydrates, proteins, fats, vitamins, minerals and variety of essential nutrients. It is also known by its high water content and nearly neutral pH (Birhanu Mekibib et al; 2010). These rich nutritional contents and the production and processing procedures in commercial milk production render it susceptible to contamination by pathogenic microbes that could cause diseases in humans. Therefore, milk is known to be an efficient vehicle for transmission of disease causing agents to humans (Getahun Teka, 1997).

Bacterial contamination could arise from the cow's udder, barn, milk collection materials, various ingredients added to dairy products and dairy farm workers. Gram-positive bacteria species which are the target of the present study, have been reported to contaminate milk as a consequence of milking cows affected by mastitis and from poorly sanitized utensils used during milking, transportation and storage processes. Gram-positive bacteria are found widely distributed in the environment and the common milk contaminants are categorized under this group of bacteria (Bisrat Godefay and Bayleyegn Molla, 2000). These bacterial contaminants result in spoilage of milk and dairy products whenever there are appropriate growth conditions for these microorganisms to outgrow psychotropic bacteria. In general, contamination with psychotropic microflora has been associated with bedding material, untreated water, soil, and vegetation (Kurwijilla et al; 1992; Wolfson et al; 1993).

Measures to reduce and prevent the growth of contaminating bacteria in milk involve limiting contamination levels and maintenance of cold storage temperatures immediately after milking. The primary hygienic practices required to limit the bacterial burden include cleaning, sanitizing and drying cow's teats and udder before milking and using sanitized milking equipment. Removal of residual solid milk from milk containers is critical in the control of psychotropic bacteria (Frank and Koffi, 1990). Defects in milk caused by lactic acid producing and coliform bacteria can be controlled by good sanitation practices, cooling below $7^{\circ} \mathrm{C}$, pasteurization and refrigeration of pasteurized milk (Slaughuis, 1996; Doyle et al; 2001). Pasteurization of milk has been practiced as the most effective method of reducing the risk of contamination and spread of disease. Although pasteurized milk is expected to have a shelf life of 14 to 20 days, the shelf life of pasteurized milk stored at ambient temperature is dependent upon the efficiency of pasteurization process. Residual bacterial populations in 
processed products are determined by initial numbers and types of bacteria in raw milk, time and temperature combination used to process milk, and care taken to prevent recontamination of the pasteurized product (Hahn, 1996). In general, in order to provide safe and healthy milk products, the Hazard Analysis and Critical Control Points (HACCP) system should be implemented starting from milk collection, through processing and storage. Microbial exposure assessments are critical components of the risk analysis (FAO/WHO, 1997; NACMF, 1998; Tetemike Mehari, 1988). In countries with poor milk production and marketing practices, one can expect a higher frequency of bacterial contamination, which poses health hazards as well as spoilage of large quantities of milk. In the current study area in particular, and in Ethiopia in general, there is lack of information on the extent of raw and pasteurized milk contamination by gram-positive bacteria, despite the practice of door-to-door milk delivery by producers, and the prevailing habit of raw milk consumption in the country. In addition, to our knowledge, there has been no established milk quality control system. Therefore, the present study was conducted to provide base-line information on the quality of milk in order to identify critical control points, starting from site of production all the way to consumption by the public.

\section{Materials and methods}

\section{Study area}

This study was carried out in the town of Gondar, Northwestern part of Ethiopia. Gondar town is situated at longitude and latitude of $12.3-13.8^{\circ} \mathrm{N}$, and 35.3-35. $7^{\circ} \mathrm{E}$, respectively and 2200 meter above sea level, respectively. The annual mean minimum and maximum temperature of the area vary between 12.3-17.7 and $22-30^{\circ} \mathrm{C}$, respectively. The town receives a bimodal rainfall, the average annual precipitation rate being $1000 \mathrm{~mm}$ due to long (from June to September) and short (March to April) rainy seasons (CSA, 2003).

\section{Ethical clearance}

Ethical clearance was obtained from University of Gondar (Reference No $\mathrm{R} / \mathrm{P} / \mathrm{O} / 04 / 436 / 07 / 08)$. Informed written consent was also obtained from all study participants and confidentiality was assured by the use of codes in records. 


\section{Study design}

A cross-sectional study was conducted from October 2010 to May 2011 to detect and identify gram-positive bacterial contaminants in raw and pasteurized milk commonly consumed by the public. A pre-tested questionnaire was administered to lactating cow owners and workers to identify and evaluate potential risk factors that might influence the quality of milk. Risk factors considered in the current study were sanitary conditions of the barn, hygiene of cow's udder and milk handlers, sanitation of containers, transportation and storage facilities, and shelf life of the pasteurized milk.

\section{Data collection and analysis}

Simple random sampling technique was employed to select critical control points and all accessible samples were collected from all selected critical control points during sample collection within the time frame of the study period. All possible accessible samples were collected during the study period. Isolation and identification of bacterial species was carried out by conventional culture based techniques and biochemical assays. The data was entered into Microsoft Excel spreadsheet and analyzed using Stata 11 and description statistics was also used as needed.

\section{Sample collection and transport}

Milk samples were collected from points (critical control points: CCPs) considered to be associated with contamination. The CCPs were the teat during milking (CCP-1), milking bucket at farm level (CCP-2), transport containers at milk collection centers (CCP-3), transportation containers up on arrival at the processing plant (CCP-4) and randomly selected pasteurized milk from pasteurization plant and at different time points from retailers (CCP-5). Overall, 108 raw and pasteurized milk samples were analyzed: of these, 93 were raw milk samples from CCP-1 $(n=37), \operatorname{CCP}-2(n=33), \operatorname{CCP}-3(n=10)$, and CCP-4 $(n=13)$ and the remaining 15 were pasteurized milk samples from the processing plant and different retailer shops.

During sampling of raw milk directly from teats, the udder and teats were cleaned and dried before sampling; each teat end was scrubbed gently with cotton swabs moistened with $70 \%$ ethyl alcohol. The first 3-4 streams of milk were discarded, and approximately $10 \mathrm{ml}$ of milk was collected into sterile sampling bottles. Samples from other CCPs were collected without interference to the local practices. All milk samples were collected in the morning following 
standard procedures. Prior to sampling from milking buckets and transport containers, the milk was thoroughly mixed by shaking and $25 \mathrm{ml}$ of milk was transferred into a sterile screw capped bottle. Transportation of samples to the Microbiology Laboratory of Faculty of Veterinary Medicine, University of Gondar, was immediately conducted for further processing using ice packs following the standard safety procedures (Robinson, 2002).

\section{Isolation and identification of gram-positive bacteria}

Isolation and identification of gram-positive bacterial pathogens were determined following aseptic sampling techniques as previously described (Quinn et al; 2002; Barrow and Feltham, 2004). Briefly, a loop full $(0.01 \mathrm{ml})$ of milk sample was streaked on 7\% blood agar (Oxoid, Germany) and incubated aerobically at $37^{\circ} \mathrm{C}$. The plates were checked for bacterial growth after $24,48,72$ hours and a week to rule out slow growing micro-organisms and sub-cultured again on $7 \%$ blood agar at $37^{\circ} \mathrm{C}$ for 24 hours to get pure culture. A single colony from a pure culture was then subjected to Gram's staining to observe gram staining and morphological characteristics and transferred to brain heart infusion agar to be grown for further analysis. Slow growing (taking a week or more) and pigment producing colonies were subjected to Modified Ziehle Neelsen staining. Identification of bacteria to the species level was carried out based on their colony and hemolytic characteristics, Gram's staining and morphological characteristics, catalase, urease and oxidase tests, hydrogen sulfide $\left(\mathrm{H}_{2} \mathrm{~S}\right)$ production, indole, methyl red (MR) and Voges-Proskauer (VP) reaction, citrate utilization, oxidation-fermentation test, motility, and different carbohydrate testes.

\section{Results}

\section{Questionnaire survey}

All farms included in this study had 1-6 cross-breed (Holstein-Friesian with indigenous) lactating cows with 50-75\% exotic blood levels. About 8.5\%, 59.6\%, $17.0 \%$, and $14.9 \%$ of the farmers cleaned their barn twice per day, once per day, three times per week and once per week, respectively. Bedding condition of the barn in $66 \%$ of the cases was poor. A quarter of dairy cows owners did not wash their cows' udder before milking. Thirty-seven percent, $26 \%, 8.7 \%$, and $2.4 \%$ of dairy farm owners washed their cows' udders by warm tap water, cold river water, cold tap water, and warm river water, respectively. But none of the farmers used detergents, disinfectants or teat dips to clean teats and udders. In addition, none of them dried the udders before milking. Most of the farmers 
(83\%) cleaned their milking utensils once in a day but the remaining (17\%) farmers cleaned their milking utensils twice per day (4.3\%) or once per two days $(12.8 \%)$ using detergents. Hot water, which is indispensable for cleaning milking equipments, was used only by $44.7 \%$ of the farmers. Around $64 \%$ of the dairy farmers used traditional flavorings, such as smoke for the betterment of the smell of milking and transport equipments as shown in Table 1.

Table 1: Hygienic practices of dairy farms in Gondar town.

\begin{tabular}{|c|c|c|c|}
\hline Farmers practices & Performance & $\begin{array}{c}\text { Number } \\
\text { farmers }\end{array}$ & $\begin{array}{r}\text { Frequency } \\
(\%)\end{array}$ \\
\hline \multirow[t]{4}{*}{ Barn cleaning } & Twice per day & 4 & $8.5 \%$ \\
\hline & Once per day & 28 & $59.58 \%$ \\
\hline & Three times per week & 8 & $17.03 \%$ \\
\hline & Once per week & 7 & $14.89 \%$ \\
\hline \multirow[t]{5}{*}{ Udder washing before milking } & No washing at all & 13 & $27.66 \%$ \\
\hline & Using warm tape water & 17 & $36.17 \%$ \\
\hline & Using cold tape water & 4 & $8.51 \%$ \\
\hline & $\begin{array}{l}\text { Using warm river } \\
\text { water }\end{array}$ & 1 & $2.13 \%$ \\
\hline & Using cold river water & 12 & $25.53 \%$ \\
\hline \multirow[t]{3}{*}{ Milking utensils cleaning } & Twice per day & 2 & $4.25 \%$ \\
\hline & Every day & 39 & $82.98 \%$ \\
\hline & Every other day & 6 & $12.77 \%$ \\
\hline \multirow{2}{*}{$\begin{array}{l}\text { Milking utensils cleaning } \\
\text { methods }\end{array}$} & Hot water & 21 & $44.68 \%$ \\
\hline & Cold water & 26 & $55.52 \%$ \\
\hline \multirow[t]{2}{*}{ Use of flavoring } & Traditional flavoring & 30 & $63.83 \%$ \\
\hline & $\begin{array}{l}\text { No use of traditional } \\
\text { flavoring }\end{array}$ & 17 & $36.17 \%$ \\
\hline \multirow[t]{2}{*}{ Hand washing before milking } & Yes & 44 & $93.62 \%$ \\
\hline & No & 3 & $6.38 \%$ \\
\hline
\end{tabular}

Of the total dairy cow owners, $93.6 \%$ of them washed their hands before milking using detergent out of which $52.3 \%$ and $47.7 \%$ used river and tap water, respectively. Milk collection workers at the sites of collection tested the quality and freshness of milk before individual farmers' milk is added to the bulk tank milk. 


\section{Prevalence of gram positive bacterial species across different CCPs}

Of 108 milk samples collected from all critical control points, $95.4 \%$ were culture positive for gram-positive bacteria. The isolates were categorized under 16 different species (Table 2). Out of the 37 milk samples collected directly from cows' udder (CCP-1), 91.9\% yielded gram-positive staining bacteria. Staphylococcus aureus $(\mathrm{N}=10)$, Rhodococcus Equi $(\mathrm{N}=10)$, Staphylococcus chromogenes $(\mathrm{N}=8)$, and Staphylococcus intermedius $(\mathrm{N}=4)$ were commonly identified isolates. At this sampling point, 2 and 7 samples were contaminated by 3 and 2 mixed bacterial species, respectively.

All the 33 samples collected from milking bucket (CCP-2) were culture positive. Twelve samples were contaminated by two different gram-positive staining bacterial species. Staphylococcus aureus $(\mathrm{N}=10)$, Rhodococcus equi $(\mathrm{N}=7)$, Nocardia asteroids $(\mathrm{N}=6)$, Bacillus cereus $(\mathrm{N}=5)$ and Staphylococcus intermedius $(\mathrm{N}=4)$ were isolated relatively at higher frequencies from this critical control point. All of the samples collected from storage containers at CCP-3 before transportation to the main pool were culture positive. Three samples had more than one bacterial species. Commonly identified isolates at this sampling point were Rhodococcus equi $(\mathrm{N}=4)$ and Bacillus cereus $(\mathrm{N}=3)$. Similarly, all milk samples collected from transportation containers upon arrival to the processing plant (CCP-4) showed gram-positive staining bacterial contamination. One sample had mixed bacterial contamination; Staphylococcus aureus and Bacillus cereus. 
Table 2: Bacterial species isolated from raw and pasteurized milk samples from various critical control points in milk production chain.

\begin{tabular}{|c|c|c|c|c|c|c|}
\hline \multirow{2}{*}{ Isolates } & \multicolumn{6}{|c|}{ Frequency and percentage of isolates by source: $N(\%)$} \\
\hline & $\begin{array}{c}\text { CCP-1 } \\
\text { (37) }\end{array}$ & $\begin{array}{c}\text { CCP-2 } \\
\text { (33) }\end{array}$ & $\begin{array}{c}\text { CCP-3 } \\
\text { (10) }\end{array}$ & $\begin{array}{l}\text { CCP-4 } \\
\text { (13) }\end{array}$ & $\begin{array}{c}\text { CCP-5 } \\
\text { (15) }\end{array}$ & $\begin{array}{l}\text { Total } \\
(108)\end{array}$ \\
\hline $\begin{array}{l}\text { Staphylococcus } \\
\text { aureus }\end{array}$ & $10(22.22)$ & $10(22.22)$ & 0 & $3(21.43)$ & $4(17.39)$ & $27(19.29)$ \\
\hline $\begin{array}{l}\text { Staphylococcus } \\
\text { intermedius }\end{array}$ & $4(8.89)$ & $4(8.88)$ & $1(7.69)$ & $1(7.14)$ & $2(8.7)$ & $12(8.57)$ \\
\hline Staphylococcus hyicus & $2(4.44)$ & $2(4.44)$ & $1(7.69)$ & 0 & $1(4.35)$ & $6(4.30)$ \\
\hline $\begin{array}{l}\text { Staphylococcus } \\
\text { epidermedius }\end{array}$ & $2(4.44)$ & $1(2.22)$ & $1(7.69)$ & $1(7.14)$ & $2(8.70)$ & $7(5.00)$ \\
\hline $\begin{array}{l}\text { Staphylococcus } \\
\text { chromogenes }\end{array}$ & $8(17.78)$ & 0 & $1(7.69)$ & $1(7.14)$ & 0 & $10(7.14)$ \\
\hline Staphylococcus lentus & $1(2.22)$ & $2(4.44)$ & 0 & 0 & 0 & $3(2.14)$ \\
\hline $\begin{array}{l}\text { Staphylococcus } \\
\text { saprophyticus }\end{array}$ & $2(4.44)$ & 0 & 0 & 0 & 0 & $2(1.43)$ \\
\hline Micrococcus species & $1(2.22)$ & $3(6.67)$ & $1(7.69)$ & $2(14.29)$ & 0 & $7(5.00)$ \\
\hline $\begin{array}{l}\text { Streptococcus } \\
\text { agalactiae }\end{array}$ & $2(4.44)$ & $2(4.44)$ & 0 & 0 & 0 & $4(2.86)$ \\
\hline Enterococcus fecalis & 0 & $1(2.22)$ & 0 & 0 & 0 & $1(0.71)$ \\
\hline Rhodococcus equi & $10(22.22)$ & $7(15.56)$ & $4(30.77)$ & $2(14.29)$ & $3(13.04)$ & $26(18.57)$ \\
\hline Bacillus cereus & 0 & $5(11.11)$ & $3(23.08)$ & $2(14.29)$ & $8(34.78)$ & $18(12.86)$ \\
\hline Nocardia asteroids & $1(2.22)$ & $6(13.33)$ & 0 & 0 & $1(4.35)$ & $8(5.71)$ \\
\hline Actinomyces pyogenes & 0 & $1(2.22)$ & 0 & 0 & $2(8.70)$ & $3(2.14)$ \\
\hline Actinomyces viscosus & $1(2.22)$ & $1(2.22)$ & $1(7.69)$ & 0 & 0 & $3(2.14)$ \\
\hline $\begin{array}{l}\text { Corynebacterium } \\
\text { bovis }\end{array}$ & $1(2.22)$ & 0 & 0 & $2(14.29)$ & 0 & $3(2.14)$ \\
\hline Total & 45 & 45 & 13 & 14 & $\mathbf{2 3}$ & 140 \\
\hline
\end{tabular}

Numbers in the parenthesis in front of each CCP indicates number of samples.

From pasteurized milk, which is ideally considered to be free of any pathogenic microorganisms, samples collected from the pasteurization plant and various supermarkets of different shelf life (CCP-5), 86.7\% were contaminated by gram-positive staining bacteria. Bacillus cereus $(\mathrm{N}=8)$, Staphylococcus aureus $(\mathrm{N}=4)$ and Rhodococcus equi $(\mathrm{N}=3)$ were the dominant species isolated from this critical point. 
In general, staphylococcus species were the dominant bacterial species (47.86\%) identified in the current research of which $32.15 \%$ and $15.71 \%$ were coagulase positives and negatives, respectively.

\section{Discussion}

The results of the questionnaire survey in this study indicated that most of the sampled dairy cows were reared under unclean environmental conditions and poor udder preparation. Therefore, it is likely that raw milk might be contaminated from manure, soiled bedding and soil (O'Connor and Charles 1995). In addition, water used for cleaning the milking equipment and washing hands has been associated with potential source of gram-positive staining bacterial contamination in bulk tank milk (Hogg, 2005) which might hold true in this study. Robinson (2002) suggested that prior to using detergents, it is essential that the equipment be washed with cold water to remove as much previous milk and dirt as possible followed by washing with warm water to remove fatty deposits. Afterwards, the equipment has to be washed again with warm water and stored in a clean, dry and dust free area. As the current research result reveals, this was not practiced by $44.7 \%$ of the dairy farm owners.

Majority of the gram-positive bacteria identified from different sampling points in the current study were environmental contaminants or commensals of udder of cows as previously described (LeJeune et al; 2008). Most of the isolates are mild pathogens except Staphylococcus aureus and Bacillus cereus which do have the capacity of producing enterotoxins that may result in food poisoning (Donkor et al., 2007).

Of 16 bacterial species identified, the commonly known milk contaminants including, Staphylococcus aureus, Rhodococcus equi and Bacillus cereus were isolated with a frequency of $19.3 \%, 18.6 \%$, and $12.9 \%$, respectively, which were higher than previous reports from Bahir Dar Zuria and Mecha district of Ethiopia (Asaminew Tassew and Eyasu Seifu, 2011). This might be due to poor and unhygienic bedding condition in the majority of farms and absence of teat dipping and disinfection practices in the current study. These practices have been known as critical components of mastitis prevention and control program in dairy herds (Galton et al., 1986). Species of Staphylococcus were the single largest group (47.9\%) isolated in this study which was in agreement with a report from Debre Zeit, Ethiopia, (Addis et al., 2011) but lower than a report from Pakistan (Ekici et al., 2004). 
Bacteria cultivated from milk samples collected directly from teat and farmers bucket at farm level were also dominated by Staphylococcus aureus which accounted $22.2 \%$ of the isolates at both sampling points. Similarly, highest rate of other Staphylococcus species isolation was observed at the two critical control points. Other studies have shown that milk from teat and bucket at the farm level could be contaminated with gram-positive staining bacteria present on teats, teat canal, udder surface, mastitis udder, residents milking system, and contaminated water used to clean the milking systems (Bramley et al., 1990). The apparent dominance of Staphylococcus species in this study might be due to the fact that dairy farm owners did not use detergents and disinfectants to wash cows' udder, which could have significantly reduced the level of contaminant bacteria (IDF, 1994). Detection rate was decreased in the majority of the species identified in our research all the way from udder to bulk tank milk at the pasteurization plant. This may be due to dilution effect. Overall, more diverse gram-positive staining bacteria species were isolated from CCP-1 (udder) and CCP-2 (farmers bucket).

Various bacterial species were also isolated from pasteurized milk (CCP-5). At this CCP, higher isolation rates were recorded by Bacillus cereus, Staphylococcus aureus and Rhodococcus equi with $34.8 \%, 17.4 \%$ and $13.1 \%$ frequency, respectively. Bacillus cereus has been described as an indicator of contamination from the environment by earlier report (Fromm and Boor, 2004). Our finding was in agreement with a study by Mubarack et al; (2010) that frequently isolated Bacillus cereus from pasteurized milk samples. Generally, only 2 of the 15 pasteurized milk samples were culture negatives for gram-positive bacteria. During the current study, 9 out of 15 pasteurized milk samples were contaminated with mixed gram-positive bacteria species. Earlier study has shown that microorganisms can survive pasteurization temperature if there is high initial contamination of raw milk (Mogessie Ashenafi and Fekadu Beyene, 1994). Therefore, keeping such pasteurized milk at room temperature for several hours in retail shops or at home may lead to early spoilage of milk. Psychotropic bacteria are important here because many of them can produce an extracellular thermostable proteolytic and lipolytic enzyme which enables them to survive pasteurization thus affecting the shelf life and quality of milk and milk products during storage (Bisrat Godefay and Bayleyegn Molla, 2000)

Most of the bacteria identified in the current study are indicators of poor sanitary and hygienic condition of the farms and transportation system. The high presence of Staphylococcus aureus, Rhodococcus equi and Bacillus cereus in 
the milk samples imply that environmental contamination could have occurred and also sub-clinically ill cows might have served as the cause of the microbial contamination. Traditional practices are likely to contribute to the contamination of the milk and proliferation of the micro-organisms. The implication is that there is high risk of acquiring food-borne diseases since $36 \%$ of the residents have the habit of consuming unpasteurized milk. It is therefore essential to implement control measures at each critical control points identified in our investigation.

\section{Conclusion}

Isolation of diverse gram-positive bacteria including common milk contaminants such as Bacillus cereus, Staphylococcus aureus and Rhodococcus equi from raw and pasteurized milk samples may be explained by higher level contamination of milk along the path. It is recommended that educating the dairy farm owners about microbial safety procedures from the point of udder sanitary processes to the sanitary practices at collection centers, should be mandatory to improve the hygienic quality of milk and minimize contamination. Furthermore, clean and easily accessible water should be provided for dairy farm owners who currently do not have such access. Finally, hazard analysis critical control point system implementation and control measures from farm to post pasteurization milk handling should be undertaken in order to minimize foodborne diseases in this area.

\section{Acknowledgements}

University of Gondar is greatly acknowledged for funding and all rounded technical assistance for the smooth accomplishment of this research.

\section{References}

Addis M., Pal M. and Kyule M.N., 2011. Isolation and identification of staphylococcus species from Ethiopian cottage cheese (Ayib) in Debre Zeit, Ethiopia. Vet. Res., $4(1), 13-17$.

Ashenafi, M. and Beyene, F., 1994. Microbial load, microflora and keeping quality of raw and pasteurized milk from dairy farm. Bull. Anim. Hlth. Prod. Afri., 42, 55-59.

Barrow G.I. and Feltham R.K. A., 2004. Identification of medical bacteria. In: Cowan and Steel's manual for the identification of medical bacteria, Cambridge University Press, UK, 39-725. 
Bramley A. J., McKinnon C. H. and Robinson R. K., 1990. The Microbiology of raw milk. J. Dairy Sci., 1, 163-208.

CSA (Central Statistical Authority)., 2003. Central statistical investigatory report. Central Statistical Authority, Federal Democratic Republic of Ethiopia, Addis Ababa, Ethiopia.

Donkor, E.S., Aning, K.G. and Quaye, J., 2007. Bacterial contaminations of informally marketed raw milk in Ghana. Ghana Med. J., 41, 58-61.

Doyle, M.P., Beuchat, L.R. and Montville, T.J., 2001. Food microbiology: fundamentals and frontiers, $2^{\text {nd }}$ ed. USA: ASM press, 793-805.

Ekici, K., Bozkurt, H. and Isleyici, O., 2004. Isolation of some pathogens from raw milk of different milk animals. Pak. J. Nutri., 3, 161-166.

FAO/WHO, 1997. Risk management and food safety. FAO food and nutrition document, Food and Agriculture Organization, Paper Number 65, Rome, Italy.

Frank J. F. and. Koffi R. A., 1990. Surface-adherent growth of Listeria monocytogenes is associated with increased resistance to surface sanitizers and heat. J. Food Prot., $53,560-564$.

Fromm, H.I. and Boor, K.J., 2004. Characterization of pasteurized fluid milk shelf-life attributes. J. Food Sci., 69207-69214.

Galton D. M., Petersson L. G. and Merril W. G., 1986. Effects of pre-milking udder preparation on bacterial counts of in milk and on teat. J. Dairy Sci., 69, 260-266.

Godefay, B. and Molla, B., 2000. Bacteriological quality of raw milk from four dairy farms and milk collection center in and around Addis Ababa. Berl. Münch. Tierärzt. Wschr., 113:1-3.

Hahn G., 1996. Pathogenic bacteria in raw milk-situation and significance of pathogenic microorganisms in raw milk. International dairy federation (IGF), Brussels, Belgium, 68-77.

Hogg S., 2005. Industrial and food microbiology. In: Essential Microbiology, University of Glamorgan, John Wiley \& Sons Ltd, UK, 407-413.

IDF (International Dairy Federation)., 1994. The significance of pathogenic micro-organisms in raw milk. J. Dairy Sci., 15, 8-11.

Kurwijilla, R.L., Hansen, K.K., Macha, I.E., Abdallah, K. and Kadigi, H.J.S., 1992. The bacteriological quality of milk from hand and machine milked dairy herds in Morogoro, Tanzania. Afri. Livestock Res., 2, 59-67.

LeJeune, J.T. and Rajala-Schultz, P.J., 2008. Unpasteurized milk: A continued public health threat. J. Food Saf., 4893-48100. 
Mehari, T., 1988. Thermoduric and psychrophilic bacteria from raw milk. MSc Thesis, Faculty of Science, Addis Ababa University, Addis Ababa, Ethiopia.

Mekibib, B., Furgasa, M., Abunna, F., Megersa, B. and Regassa, A., 2010. Bovine Mastitis: Prevalence, risk factors and major pathogens in dairy farms of Holeta town, central Ethiopia. Vet. World, 397-403.

Mubarack, H.M., Doss, A., Dhanabalan, R. and Balachander, S., 2010. Microbial quality of raw milk samples collected from different villages of Coimbatore district, Tamilnadu, South India. Ind. J. Sci. Tech., 361-63.

NACMF (National Advisory Committee on Microbiological criteria for Food). 1998. Hazard analysis and critical control point principles and applications guidelines. J. Food Prot., 61762-61775.

O'Connor, and Charles B., 1995. Rural dairy technology, ILRI training manual 1, Addis Ababa, Ethiopia.

Quinn, P.J., Markey, B.K., Carter, M.E., Donnely, W.J. and Leonard, F.C., 2002. Pathogenic bacteria. In: Veterinary microbiology and microbial diseases. Blackwell Publishing Agency, 43-250.

Robinson R. K., 2002. The microbiology of milk and milk products. In: Dairy microbiology handbook, Third Edition, John Wiley \& Sons, Inc, 51-305.

Slaughuis, B., 1996. Sources and significance of contaminants on different levels of raw milk production. In: Symposium on bacteriological quality of raw milk. International dairy Federation proceedings, Brussels, Belgium.

Tassew, A. and Seifu E., 2011. Microbial quality of raw cow's milk collected from farmers and dairy cooperatives in Bahir Dar Zuria and Mecha district, Ethiopia. Agri. Biol. J. N. Am., 2(1), 29-33.

Teka, G., 1997. Food Hygiene principles and food borne disease control with special reference to Ethiopia. Faculty of Medicine, Department of Community Health, Addis Ababa University, 73-86.

Wolfson, L.M. and Summer, S.S., 1993. Antibacterial activity of the lactoperoxidase system: a review. J. Food Prot., 56887-56892. 